\title{
Communication
}

\section{Light-driven activation of carbon-halogen bonds by readily available amines for photocatalytic hydrodehalogenation}

\author{
Di Meng a,b,†, Qian Zhu a,b,t,ł, Yan Wei a,b, Shengli Zhen c, Ran Duan a, Chuncheng Chen a,b, \\ Wenjing Song a,b,*, Jincai Zhao a,b \\ a Key Laboratory of Photochemistry, CAS Research/Education Center for Excellence in Molecular Sciences, Institute of Chemistry, Chinese Academy of \\ Sciences, Beijing, 100190, China \\ b University of Chinese Academy of Sciences, Beijing, 100049, China \\ ' Beijing GeoEnviron Engineering \& Technology, Inc., Beijing, 100095, China
}

\section{A R T I C L E I N F O}

\section{Article history:}

Received 20 January 2020

Accepted 5 March 2020

Published 5 October 2020

\section{Keywords:}

Carbon-halogen bond activation

Photocatalysis

Halogenated organic pollutants

Reductive dehalogenation

Environmental remediation

\begin{abstract}
A B S T R A C T
A straightforward protocol using readily available aromatic amines, $N, N, N N^{\prime}, N^{\prime}$-tetramethylp-phenylenediamine or $N, N, N^{\prime}, N^{\prime}$-tetramethylbenzidine, as photocatalysts was developed for the efficient hydrodehalogenation of organic halides, such as 4 '-bromoacetophenone, polyfluoroarenes, cholorobenzene, and 2,2',4,4'-tetrabromodiphenyl ether(a resistant and persistent organic pollutant). The strongly reducing singlet excited states of the amines enabled diffusion-controlled dissociative electron transfer to effectively cleave carbon-halogen bonds, followed by radical hydrogenation. Diisopropylethylamine served as the terminal electron/proton donor and regenerated the amine sensitizers.
\end{abstract}

(C) 2020, Dalian Institute of Chemical Physics, Chinese Academy of Sciences. Published by Elsevier B.V. All rights reserved.
Light-driven activation of carbon-halogen bonds (C-X) has become a powerful approach for constructing new chemical bonds in valuable pharmaceutical and industrial intermediates, as well as for the elimination of polyhalogenated aromatic pollutants [1-8]. Essentially, the process relies on high-energy excited states/intermediates that trigger electron transfer to cleave carbon-halogen bonds $\left(\mathrm{C}-\mathrm{X}+\mathrm{e}^{-} \rightarrow \mathrm{C} \bullet+\mathrm{X}^{-}\right.$, dissociative electron transfer), affording carbon radicals that can engage in diverse reactions, including hydrogenation and cross coupling [9-18]. For a thermodynamically favored process, energy levels of the photogenerated species should locate above the an- ti-bonding $\sigma^{*}$ or $\pi^{*}$ orbital of halogenated substrates. Promising results have been reported with classical photosensitizers, $\mathrm{Ru}(\mathrm{bpy}) 3^{2+}$ and $f a c$ - $\operatorname{Ir}(\mathrm{ppy})_{3}$ (bpy is 2,2'-bipyridine and ppy is 2-phenylpyridine), where their triplet excited states $(-0.8$ and -1.7 V vs. SCE) $[1,19]$, or the reduced complexes $(-1.3$ and -2.1 $\mathrm{V}$ vs. SCE) enable dissociative electron transfer. Recently, hexachlorocerate(III) ( $\left.\mathrm{Ce}^{\mathrm{III}} \mathrm{Cl}_{6}{ }^{3-}\right)$, with a strongly reducing excited state $\left(-3.45 \mathrm{~V}\right.$ vs. $\left.\mathrm{Fc} / \mathrm{Fc}^{+}\right)$, has been developed as a sensitizer for the reduction of aryl chlorides under UVA irradiation $[20,21]$. Copper complexes are likewise involved in conversions of carbon-halogen bonds [22,23], e. g., C-F functionalization

\footnotetext{
* Corresponding author. Tel: +86-10-82615942; Fax: +86-10-82612075; E-mail: wsongunc@iccas.ac.cn

† These authors contributed equally to this work.

₹ Current Address: Beijing GeoEnviron Engineering \& Technology, lnc., Beijing, 100095, P. R. China.

This work was supported by the National Key R\&D Program of China (2018YFA0209302), National Natural Science Foundation of China (21590811, 21677148, 21827809, 21922609), the Key Research Program of Frontier Sciences (QYZDY-SSW-SLH028) of the Chinese Academy of Sciences. DOI: 10.1016/S1872-2067(20)63582-3 | http://www.sciencedirect.com/science/journal/18722067 | Chin. J. Catal., Vol. 41, No. 10, October 2020
} 


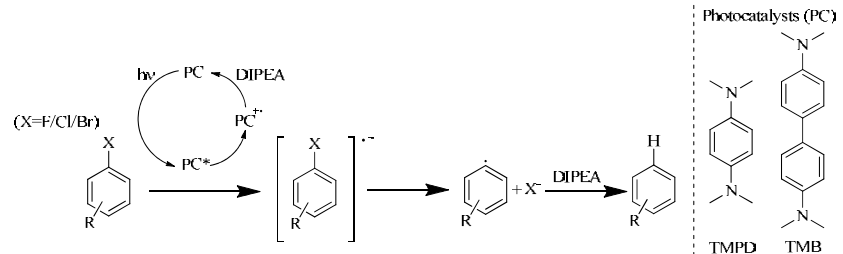

Scheme 1. Working hypothesis of the photocatalytic hydrodehalogenation.

under pulsed light-emitting diodes (LEDs) [24]. Organic sensitizers, such as diaryl dihydrophenazines [25], phenylphenothiazine [26,27], perylene diimide[28] and pyrene [2], are also efficient photosensitizers, producing active reducing species ( -2.06 to $-2.5 \mathrm{~V}$ vs. SCE) via photon upconversion or consecutive two-photon absorption. These organic molecules are more cost effective and less prone to deactivation (e.g., halogen coordination in the case of transition metal catalysts) [3,26,27]. Halogen bonds or $\pi-\pi$ interaction between catalyst and substrate may further facilitate bond activation via an inner sphere electron transfer pathway, however synthetic efforts are required in order to modulate the intermolecular interactions $[15,29]$.

Herein, we establish a metal- and additive-free photocatalytic system based on a $N, N, N, N^{\prime}$-tetramethyl- $p$-phenylenediamine (TMPD), or $N, N, N^{\prime}, N^{\prime}$-tetramethylbenzidine (TMB) sensitizer featuring strongly reducing excited singlet states and diisopropylethylamine (DIPEA) as an electron/proton donor, for hydrodehalogenation of a variety of haloarenes under UV irradiation $(\lambda>360 \mathrm{~nm})$. In this approach, photogenerated
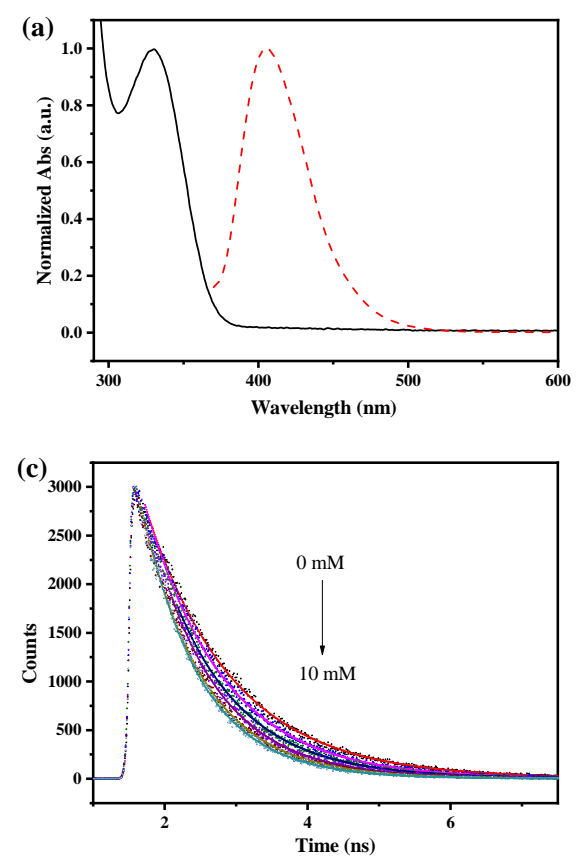

Fig. 1. (a) Absorption (solid line) and emission (dashed line) spectra of TMPD; (b) Changes in the emission intensity of TMPD upon addition of hexafluorobenzene. Note that the absorbance at the excitation wavelength did not change (inset); (c) Changes in the emission lifetime of TMPD; (d) Plots of the relative emission intensities (black) and lifetimes of TMPD (red) obtained from (b) and (c) against hexafluorobenzene concentration. All measurements were conducted in acetonitrile at room temperature. sion-controlled electron transfer to halogenated substrates, followed by cleavage of the $\mathrm{C}-\mathrm{X}$ to give an aryl radical; subsequent radical hydrogenation affords the dehalogenated product (Scheme 1).

TMPD displays $\mathrm{S}_{0}-\mathrm{S}_{1}$ absorption extended to $380 \mathrm{~nm}$ (Fig. 1(a)). In the presence of selected aryl halides (4'-bromoacetophenone, hexafluorobenzene and chlorobenzene), TMPD absorption variations were negligible, excluding the interaction of the TMPD ground state with these compounds. The viability of TMPD in photo-induced activation of carbon-halogen bonds was initially evaluated by steady-state and time resolved emission spectroscopies. The emission intensity of TMPD ( $0.1 \mathrm{mM}, 360 \mathrm{~nm}$ excitation) decreased upon introduction of all three substrates (2-10 mM, Fig. 1(b) and Fig. S1), which is consistent with an electron transfer from the singlet excited states to these compounds. The emission lifetime measured at $405 \mathrm{~nm}$ likewise decreased (Fig. 1(c)). The parallel Stern-Volmer plot of emission intensity and lifetime (Fig. 1(d)) indicates an outer sphere electron transfer to hexafluorobenzene, with negligible contribution of static quenching via a pre-associated ground state complex, in agreement with the unchanged absorption spectra [30-32]. The rate constants calculated by Stern-Volmer analysis (Fig. S1) were $5.8 \times 10^{10}$ $\mathrm{M}^{-1} \mathrm{~s}^{-1}$ for $4^{\prime}$-bromoacetophenone, $4.4 \times 10^{10} \mathrm{M}^{-1} \mathrm{~s}^{-1}$ for hexafluorobenzene and $2.6 \times 10^{10} \mathrm{M}^{-1} \mathrm{~s}^{-1}$ for chlorobenzene (Fig. S1). Notably, the observed electron transfer is diffusion-limited, even in the case of exceptionally inert chlorobenzene [20]. For TMB, the electron transfer to hexafluorobenzene was also likewise diffusion-limited $\left(3.6 \times 10^{10} \mathrm{M}^{-1} \mathrm{~s}^{-1}\right)$, but became activa-
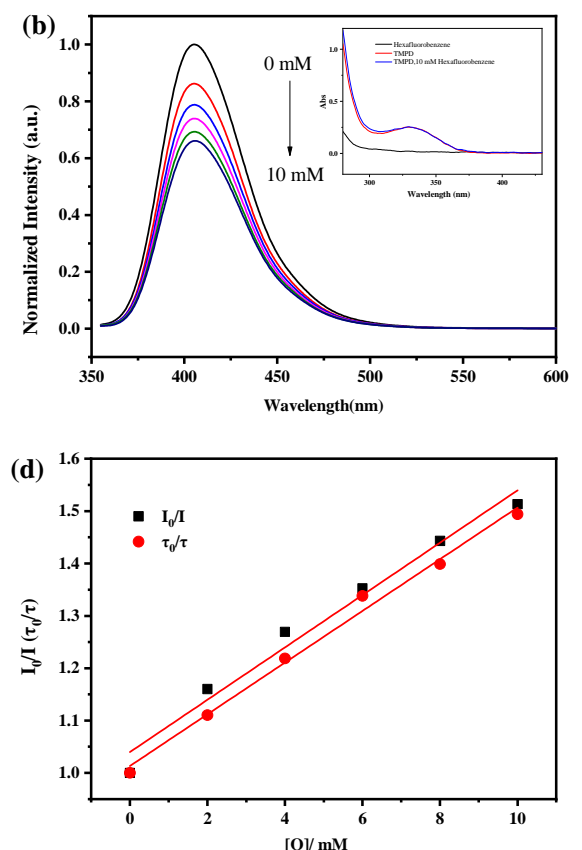

excited states of the amine sensitizers enable diffu- 
tion-controlled in the case of chlorobenzene $\left(6.2 \times 10^{9} \mathrm{M}^{-1} \mathrm{~s}^{-1}\right.$, Fig. S1). The slower electron transfer observed for TMB could be attributed to the fact that its excited state energy is lower than that of TMPD ( -3.48 and $-3.56 \mathrm{vs}$. $\mathrm{Fc} / \mathrm{Fc}^{+}$, respectively) [33]. These results established a kinetically feasible electron transfer, the initial step for hydrodehalogenation [6].

In the initial test, where 4 '-bromoacetophenone $(1 \mathrm{mM})$ was used as the model substrate with a stoichiometric amount of TMPD (2:1 according to the $2 \mathrm{e} / 1 \mathrm{H}^{+}$process) as the photoreductant, a conversion of $86 \%$ with a selectivity of $90 \%$ for hydrodebromination was observed after $6 \mathrm{~h}$ of irradiation (Table 1 , entry 1). The quantitative production of bromide was additionally confirmed by ionic chromatography (Fig. S2). Involvement of aryl radical intermediates via the initial electron transfer was supported by the generation of $\mathrm{C}-\mathrm{C}$ coupled products in the presence of $N$-methyl pyrrole (Fig. S3) [3,34]. In situ electron paramagnetic resonance (EPR) experiments and the simulated EPR spectra also suggested the generation of TMPD ${ }^{+}$. and an acetophenone radical (via $\mathrm{C}-\mathrm{Br}$ bond cleavage of the 4'-bromoacetophenone radical anion) (Fig. S4 and Table S1). The aryl radical then abstracts a hydrogen atom from TMPD/TMPD ${ }^{+}$to give the hydrogenated product. TMB exhibited comparable activity under these conditions, with a yield of 88\% (Table S2). Control experiments confirmed that photoirradiation and amines were essential for efficient hydrodehalogenation. The highest hydrodebromination yield was obtained in acetonitrile, while significantly inferior yields were observed with dimethylformamide (27\%), methanol (20\%), dichloromethane $(17 \%)$, and n-hexane $(10 \%)$ (Table S2). For hexafluorobenzene (Table 1, entry 2), both mono- and di-defluorination products were observed after $5 \mathrm{~h}$ of reaction time, albeit in relatively low yields (pentafluorobenzene, $26 \%$, $1,2,4,5$-tetrafluorobenzene, $17 \%$ ). It is possible that the fluorinated aryl radical engages in other processes due to the lack of efficient $\mathrm{H}$ donors. Chlorobenzene also demonstrated satisfactory conversion $(63 \%$ at $5 \mathrm{~h})$ and selectivity $(80 \%$, Table 1 , entry 3).

Table 1

Photochemical reduction results of various halogenated substrates: conversion and selectivity.

\begin{tabular}{|c|c|c|c|c|}
\hline Entry & Substrate & Product & $\begin{array}{c}\text { Conversion } \\
(\%)\end{array}$ & $\begin{array}{c}\text { Selectivity } \\
(\%)\end{array}$ \\
\hline 1 & & & 86 & 90 \\
\hline $2^{a}$ & & & 91 & 26,17 \\
\hline $3 \mathrm{~b}$ & & & 63 & 80 \\
\hline
\end{tabular}

Conditions: $1 \mathrm{mM}$ substrates and $2 \mathrm{mM}$ TMPD in $20 \mathrm{~mL}$ of acetonitrile solution, irradiated by a xenon lamp with a $360 \mathrm{~nm}$ cutoff filter (the

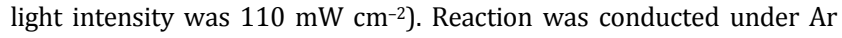
atmosphere at $298 \mathrm{~K}$. Yields were determined by high-performance liquid chromatography (HPLC) and ionic chromatography (IC).

a 4 mM TMPD. The products were identified by ${ }^{19} \mathrm{~F}$ NMR and the yields were determined by GC. b Product yields were determined by gas chromatography.
Next, we conducted the hydrodehalogenation under catalytic conditions with 5\% TMPD, using DIPEA (15 equivalents) as the electron/hydrogen donor for radical intermediates. DIPEA also reduces TMPD ${ }^{+}$to recover the photosensitizer (Fig. S5). The results are summarized in Table 2 and Fig. S6. Gratifyingly, the conversion of $4^{\prime}$-bromoacetophenone occurred smoothly, with a hydrodebromination yield of $90 \%$ (entry 1), corresponding to a turnover number (TON) of 18. The hydrodebromination yield of bromobenzene was 37\% after $6 \mathrm{~h}$ of irradiation (entry 2). Hydrodefluorination yields above $70 \%$ were obtained for hexafluorobenzene and pentafluoropyridine (enter 3 and 4). Notably, the yields of pentafluorobenzene (25\%) and the di-hydrodefluorination product, 1,2,4,5-tetrafluorobenzene (50\%, Fig. S7) were significantly higher than those obtained under stoichiometric conditions, presumably due to a more efficient hydrogenation by DIPEA/DIPEA $^{+\bullet}$. In the case of chlorobenzene, the hydrodechlorination yield approached $40 \%$ after $2 \mathrm{~h}$ of irradiation, but did not increase with extended reaction time (entry 5). The dechlorination could be resumed by the addition of TMPD ( 0.1 equivalent, Fig. S6). The hydrogenation yield of methyl 4-chlorobenzoate reached $72 \%$ after $7.5 \mathrm{~h}$ of irradiation (entry 6). In addition, the catalytic system demonstrated compatibility with halogenated heteroarenes (entries 7 and 8), affording

Table 2

Substrate scope of photocatalytic hydrodehalogenation.

Entry Time (h)

Conditions: $1 \mathrm{mM}$ of substrate, 0.05 equivalents of amine sensitizer, and 15 equivalents of DIPEA in $20 \mathrm{~mL}$ of acetonitrile solution, irradiated by a xenon lamp with a $360 \mathrm{~nm}$ cut of filter (the light intensity was 180

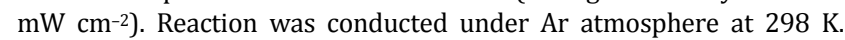
Yields were determined by HPLC and GC.

a The products were identified by ${ }^{19} \mathrm{~F}$ NMR and the yields were determined by GC. b TMB was used as the photocatalyst. c 4,4',4"--(1,3,5-triazine-2,4,6-triyl)trianiline (TTA) was used as the photocatalyst. 
moderate to good product yields. The TON of these substrates with TMPD ranged from 7.4 to 14.4. When TMB was employed as the photocatalyst, a low dechlorinated product yield of $15 \%$ was observed under the same conditions, despite extended reaction times of $20 \mathrm{~h}$ (entry 9). This result could be attributed to the weaker electron transfer driving force from TMB excited states to the halogenated substrates, compared to TMPD, as indicated by emission quenching dynamics. 4,4',4"-(1,3,5-triazine-2,4,6-triyl)-tri-aniline (TTA), which demonstrates similar absorption to TMPD, was also tested for its photocatalytic ability in the hydrodehalogenation of 4 '-bromoacetophenone (Fig. S8). The product yield after $4 \mathrm{~h}$ of irradiation reached $90 \%$ (entry 10). These results demonstrate that amine-based sensitizers are promising photocatalysts in light-driven organic transformations.

We further investigated the performance of TMPD as a photocatalyst in the debromination of 2,2',4,4'-tetrabromodiphenyl ether (BDE47), a typical persistent organic pollutant that is resistant to conventional reductive treatments $[10,35,36]$. The removal of bromines in polybrominated diphenyl ethers with low bromine substitution is challenging, as debromination becomes less thermodynamically favorable with decreasing bromine atom numbers. Under photocatalytic conditions, Pd cocatalysts are usually required to provide high degrees of debromiantion $[10,37,38]$. It was impressive to find that with 1 equivalent of catalyst and $2.5 \mathrm{v} \%$ DIPEA, BDE47 underwent facial debromination and 83\% debromination efficiency was realized after $30 \mathrm{~h}$, producing the completely debrominated product, diphenyl ether in $40 \%$ yield (Fig. S9). The distribution of debrominated intermediates, e.g., the 4:1 ratio of 2,4,4'-tribromodiphenyl ether (BDE28) to 2,2',4-tribromodiphenyl ether (BDE17), indicated a debromination preference for the ortho position, which is in accordance with an electron transfer-triggered debromination $[39,40]$.

Emission quenching kinetics and the results of photochemical/photocatalytic hydrodehalogenation are consistent with the cleavage of carbon halogen bonds via an electron transfer from singlet excited states of TMPD or TMB. Control experiments indicated that DIPEA had a negligible effect on the emis- sion of TMPD (Fig. S10), which is different from the activation of carbon-halogen bonds by the pre-photoreduced sensitizer in pyrene derivatives, and fac-Ir(ppy) 3 catalyzed hydrodehalogenation $[1,16]$. Analogous pathways have been reported for phenylphenothiazine and $\mathrm{Ce}^{\mathrm{III}} \mathrm{Cl}_{6}{ }^{3-}$ under near-UV or UVA irradiation [20]. The aromatic amines feature strongly reducing excited states, and their electron transfer kinetics are one order of magnitude faster than the activation-limited transfer from $\mathrm{Ce}^{\mathrm{III}} \mathrm{Cl}_{6}{ }^{*}$ to $4-\mathrm{F}-\mathrm{C}_{6} \mathrm{H}_{4} \mathrm{X}\left(\mathrm{X}=\mathrm{Br}, \mathrm{Cl}, \mathrm{F}, 0.9-3.0 \times 10^{9} \mathrm{M}^{-1} \mathrm{~s}^{-1}\right.$ ). Notably, the overall conversion is additionally limited by the competition of carbon-halogen bond cleavage of the aryl halide radical anion intermediates, and the non-productive thermal back electron transfer [6]. Nonetheless, the activation of $\mathrm{C}-\mathrm{Cl}$ and $\mathrm{C}-\mathrm{F}$ bonds with readily available amines is an attractive alternative for selective hydrodehalogenation under mild conditions, and in a sustainable manner. The development of related compounds with suitable excited state energies and HOMO-LUMO levels are expected to achieve visible light activity, rapid catalyst turnover and enhanced activity. These amine sensitizers, in combination with a sencond light absorber could be integrated into tandem photocatalytic systems, in order to inhibit the back electron transfer, thus favoring the cleavage of carbon-halogen bonds.

In summary, we demonstrated that excited states of amine sensitizers enable diffusion-controlled electron transfer to effectively cleave a number of highly challenging carbon-halogen bonds. Successful light-driven hydrodehalogenation of various aromatic halides and organic pollutants was achieved in the absence of hazardous reagents. This method is a practical and cost-effective strategy, enabling exceptionally high activity.

\section{References}

[1] D. M. Schultz, T. P. Yoon, Science, 2014, 343, 1239176.

[2] I. Ghosh, R. S. Shaikh, B. Konig, Angew. Chem. Int. Edit., 2017, 56, 8544-8549.

[3] I. Ghosh, T. Ghosh, J. I. Bardagi, B. Konig, Science, 2014, 346, 725-728.

[4] K. Chen, N. Berg, R. Gschwind, B. Konig, J. Am. Chem. Soc., 2017, 139, 18444-18447.

\section{Graphical Abstract}

Chin. J. Catal., 2020, 41: 1474-1479 doi: 10.1016/S1872-2067(20)63582-3

Light-driven activation of carbon-halogen bonds by readily available amines for photocatalytic hydrodehalogenation

Di Meng, Qian Zhu, Yan Wei, Shengli Zhen, Ran Duan, Chuncheng Chen, Wenjing Song *, Jincai Zhao Institute of Chemistry, Chinese Academy of Sciences; University of Chinese Academy of Sciences

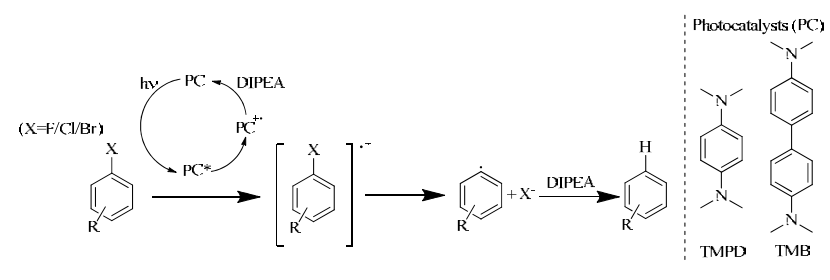

Photocatalytic system based on readily available amine sensitizers offers efficient hydrogenation of a variety of aromatic halides. 
[5] K. Shimomaki, K. Murata, R. Martin, N. Iwasawa, J. Am. Chem. Soc., 2017, 139, 9467-9470.

[6] D. Koyama, H. J. A. Dale, A. J. Orr-Ewing, J. Am. Chem. Soc., 2018, 140, 1285-1293.

[7] M. Goez, C. Kerzig, R. Naumann, Angew. Chem. Int. Ed., 2014, 53, 9914-9916.

[8] I. Ghosh, B. Konig, Angew. Chem. Int. Ed., 2016, 55, 7676-7679.

[9] C. Y. Sun, D. Zhao, C. C. Chen, W. H. Ma, J. C. Zhao, Environ. Sci. Technol., 2009, 43, 157-162.

[10] L. N. Li, W. Chang, Y. Wang, H. W. Ji, C. C. Chen, W. H. Ma, J. C. Zhao, Chem.-Eur. J., 2014, 20, 11163-11170.

[11] W. Chang, C. Y. Sun, X. B. Pang, H. Sheng, Y. Li, H. W. Ji, W. J. Song, C. C. Chen, W. H. Ma, J. C. Zhao, Angew. Chem. Int. Ed., 2015, 54, 2052-2056.

[12] Y. H. Lv, X. F. Cao, H. Y. Jiang, W. J. Song, C. C. Chen, J. C. Zhao, Appl. Catal. B, 2016, 194, 150-156.

[13] Q. Zhu, Y. Y. Wang, H. N. Zhang, R. Duan, C. C. Chen, W. J. Song, J. C. Zhao, Appl. Catal. B, 2017, 219, 322-328.

[14] Y. Y. Wang, Q. Zhu, Y. Wei, Y. J. Gong, C. C. Chen, W. J. Song, J. C. Zhao, Appl. Catal. B, 2018, 231, 262-268.

[15] J. Z. Lu, N. S. Khetrapal, J. A. Johnson, X. C. Zeng, J. Zhang, J. Am. Chem. Soc., 2016, 138, 15805-15808.

[16] S. M. Senaweera, A. Singh, J. D. Weaver, J. Am. Chem. Soc., 2014, 136, 3002-3005.

[17] M. B. Khaled, R. K. El Mokadem, J. D. Weaver, J. Am. Chem. Soc., 2017, 139, 13092-13101.

[18] C. Costentin, M. Robert, J. M. Saveant, J. Am. Chem. Soc., 2004, 126, 16051-16057.

[19] J. D. Nguyen, E. M. D'Amato, J. M. R. Narayanam, C. R. J. Stephenson, Nat. Chem., 2012, 4, 854-859.

[20] H. L. Yin, Y. Jin, J. E. Hertzog, K. C. Mullane, P. J. Carroll, B. C. Manor, J. M. Anna, E. J. Schelter, J. Am. Chem. Soc., 2016, 138, 16266-16273.

[21] L. Pause, M. Robert, J. M. Saveant, J. Am. Chem. Soc., 1999, 121, 7158-7159.

[22] H. Q. Do, S. Bachman, A. C. Bissember, J. C. Peters, G. C. Fu, J. Am.
Chem. Soc., 2014, 136, 2162-2167.

[23] S. E. Creutz, K. J. Lotito, G. C. Fu, J. C. Peters, Science, 2012, 338, 647-651.

[24] T. P. Nicholls, J. C. Robertson, M. G. Gardiner, A. C. Bissember, Chem. Commun., 2018, 54, 4589-4592.

[25] J. C. Theriot, C. H. Lim, H. Yang, M. D. Ryan, C. B. Musgrave, G. M. Miyake, Science, 2016, 352, 1082-1086.

[26] M. Haring, R. Perez-Ruiz, A. Jacobi von Wangelin, D. D. Diaz, Chem. Commun., 2015, 51, 16848-16851.

[27] R. Matsubara, T. Yabuta, U. M. Idros, M. Hayashi, F. Ema, Y. Kobori, K. Sakata, J. Org. Chem., 2018, 83, 9381-9390.

[28] J. T. Shang, H. Y. Tang, H. W. Ji, W. H. Ma, C. C. Chen, J. C. Zhao, Chin. J. Catal., 2017, 38, 2094-2101.

[29] B. Liu, C. H. Lim, G. M. Miyake, J. Am. Chem. Soc., 2017, 139, 13616-13619.

[30] S. V. Rosokha, E. A. Loboda, J. Phys. Chem. A, 2015, 119, 3833-3842.

[31] C. G. S. Lima, T. D. Lima, M. Duarte, I. D. Jurberg, M. W. Paixao, ACS Catal., 2016, 6, 1389-1407.

[32] in Principles of Fluorescence Spectroscopy (Ed.: J. R. Lakowicz), Springer US, Boston, MA, 2006, pp. 277-330.

[33] A. Banerjee, D. E. Falvey, J. Org. Chem., 1997, 62, 6245-6251.

[34] Z. Chami, M. Gareil, J. Pinson, J. M. Saveant, A. Thiebault, J. Org. Chem., 1991, 56, 586-595.

[35] M. Lei, S. Guo, Z. Y. Wang, L. H. Zhu, H. Q. Tang, Environ. Sci. Technol., 2018, 52, 11743-11751.

[36] Y. Wei, Y. J. Gong, X. Zhao, Y. Y. Wang, R. Duan, C. C. Chen, W. J. Song, J. C. Zhao, Environ.-Sci. Nano, 2019, 6, 1585-1593.

[37] H. Sakamoto, J. Imai, Y. Shiraishi, S. Tanaka, S. Ichikawa, T. Hirai, ACS Catal., 2017, 7, 5194-5201.

[38] K. Fuku, K. Hashimoto, H. Kominami, Chem. Commun., 2010, 46, 5118-5120.

[39] M. Lei, N. Wang, L. H. Zhu, H. Q. Tang, Chemosphere, 2016, 150, 536-544.

[40] Z. Hu, X. Wang, H. T. Dong, S. Y. Li, X. K. Li, L. S. Li, J. Hazard. Mater., 2017, 340, 1-15.

\title{
基于芳香胺化合物的光催化脱卤加氢
}

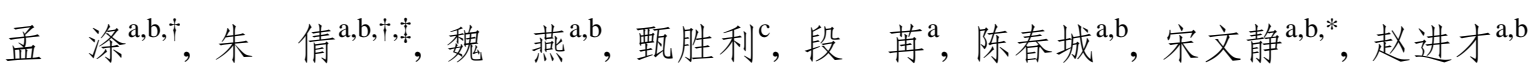 \\ ${ }^{\mathrm{a}}$ 中国科学院化学研究所光化学重点实验室, 中国科学院分子科学科教融合卓越中心, 北京 100190 \\ b 中国科学院大学, 北京100049 \\ c 北京高能时代环境技术股份有限公司, 北京100095
}

摘要: 近年来, 光催化活化碳卤键已经成为构筑新化学键的有力方法. 其基本原理在于利用光激发产生的高活性激发态或 中间物种, 经由电子转移过程实现碳卤键的断裂产生碳自由基和卤离子 $\left(\mathrm{C}-\mathrm{X}+\mathrm{e}^{-} \rightarrow \mathrm{C} \cdot+\mathrm{X}^{-}\right)$. 碳自由基通过加氢或者或 亲电进攻等途径完成反应, 实现碳卤键到碳氢、碳碳等化学键的转化. 目前已报道的用于活化碳卤键的光催化剂包括过渡 金属(如钓、铱)配合物, 过渡金属盐 $\left(\mathrm{Ce}^{\mathrm{III}} \mathrm{Cl}_{6}{ }^{3-}\right.$ )、有机小分子光(二氢苯二嗪、苯基吩噻嗪、萠酰亚胺以及萠类衍生物分子) 等.

本工作中我们开发了基于小分子芳香胺, 包括 $N, N_{,}, N^{\prime}, N^{\prime}$-四甲基对苯二胺（TMPD）与 $N, N, N^{\prime}, N^{\prime}$-四甲基联苯胺（TMB） 等作为光催化剂实现高惰性芳香卤代化合物脱卤加氢的催化体系. 荧光强度/寿命测试表明芳香胺的强还原性单重激发态 可通过扩散控制的电子转移实现惰性卤代底物 (氯苯, 六氟苯等) 中碳卤键的解离; 并且原位顺磁共振直接观察到了这一 步骤产生的芳基自由基以及TMPD正离子自由基; 自由基捕获实验也为解离电子转移活化碳卤键提供了进一步的支持.

芳香胺分子在计量反应条件下可同时作为光敏剂和电子/氢给体可在紫外光照下 $(\lambda>360 \mathrm{~nm})$ 实现芳香卤代化合物的 脱卤加氢, 并表现出较高的转化率和选择性:澳苯乙酮(86\%, 90\%)、六氟苯(91\%, 五氟苯26\%/1,2,4,5-四氟苯17\%)、氯苯(63\%, 80\%). 引入 $N, N$-二异丙基乙二胺(DIPEA)作为电子给体, 能够还原芳香胺正离子自由基完成催化剂循环, DIPEA同时作为 
氢给体参与芳基自由基加氢. 我们在催化反应条件下(5 mol\%芳香胺)调研了脱卤加氢的卤代底物范畴. 以 TMPD为例, 对 溴苯乙酮光照4小时后可得到 $90 \%$ 脱溴产物; 相对难还原的溴苯经过6小时光反应脱卤达到 $37 \%$. 六氟苯经过 24 小时反应后 可以脱去1-2个氟, 生成五氟苯(25\%)和1,2,4,5-四氟苯(50\%). 对氯苯甲酸甲酯在7.5小时反应后得到了 72\%的加氢产物; 而 对于更难还原的氯苯两小时光照可生成约 $40 \%$ 的脱氯产物(增加TMPD用量可进一步提高脱氯效率至63\%). TMPD催化杂 环卤代化合物脱卤的效果也较好, 如3-溴噻吩(18 h, 41\%)和3-溴-4甲基吡啶(25 h, 60\%). 另外TMB和4,4',4"-(1,3,5-三嗪 $-2,4,6$-三基)三苯胺作为光催化剂也可实现脱卤加氢.

我们进一步研究了典型持久性有机污染物 $2,2^{\prime}, 4,4^{\prime}$-四溴联苯醚(BDE47)的光催化脱溴反应, 30小时光照后脱溴效率可 达 $83 \%$, 并且产生了 $40 \%$ 的全脱溴产物联苯醚. 脱溴中间产物分布表明邻位溴脱除速率高于对位溴. 这一结果与解离电子 转移活化碳卤键的机理一致.

总而言之, 我们的工作表明小分子芳香胺光敏剂的激发态能够通过扩散控制的电子转移活化碳卤键. 它们作为光催 化剂可实现多种有机卤化物的脱卤加氢.

关键词: 碳卤键活化; 光催化; 脱卤加氢; 卤代有机污染物; 环境修复

收稿日期: 2020-01-20. 接受日期: 2020-03-05. 出版日期: 2020-10-05.

*通讯联系人.电话: (010)82615942; 传真: (010)82612075; 电子信箱: wsongunc@iccas.ac.cn

${ }^{\dagger}$ 相同贡献作者.

未现地址：北京高能时代环境技术股份有限公司，北京100095

基金来源：国家重点研发计划（2018YFA0209302); 国家自然科学基金(21590811，21677148，21827809，21922609); 中国科学院 前沿科学重点研究计划(QYZDY-SSW-SLH028).

本文的电子版全文由Elsevier出版社在ScienceDirect上出版(http://www.sciencedirect.com/science/journal/18722067). 